\title{
Lime Scale Water in Domestic Boilers as the Main Toxic Factor in the Human Body
}

\author{
İnsan Vücudunda Ana Toksik Faktör Olarak Evsel Kazanlardaki Kireç Birikimi Su
}

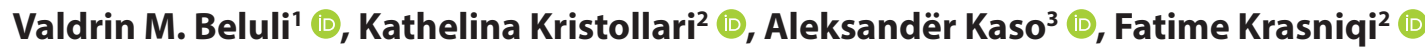 \\ 'Department of Industrial Chemistry, Faculty of Nature Sciences, Tirana University, Tirana, Albania \\ 2Department of Biotechnology, Faculty of Nature Sciences, Tirana University, Tirana, Albania \\ ${ }^{3}$ Department of Biology, Faculty of Nature Sciences, Tirana University, Tirana, Albania
}

ORCID ID: V.M.B. 0000-0003-1234-6888; K.K. 0000-0003-1494-2819; A.K. 0000-0002-7753-6941; F.K. 0000-0002-3798-2998

Cite this article as: Beluli VM, Kristollari K, Kaso A, Krasniqi F. Lime Scale Water in Domestic Boilers as the Main Toxic Factor in the Human Body. Experimed 2020; 10(2): 77-83.

\begin{abstract}
This research is based on the study of boiler water with a high content of waste inside boilers. After many years of use, a very toxic lime scale (LS) is formed in the boiler mixed with heavy elements, ions, and other molecules dangerous for human health. The high concentration of some heavy metals in domestic boilers is a problem in itself. During our study we created laboratory proof that inside domestic boilers contain extremely high concentrations of some heavy carcinogenic metals. Domestic boilers should have a simple system for cleaning the waste in the boiler that in our research contains heavy metals that can create profoundly serious problems in a person with normal metabolism. The chemical parameters analysed in the domestic boilers are: $\mathrm{Cu}(0.002-3.08)$ $\mathrm{mg} / \mathrm{L}$, Fe (0.001-0.97) mg/L, $\mathrm{Cr}^{+6}(0-0.31) \mathrm{mg} / \mathrm{L}, \mathrm{Al}^{+3}(0.001-0.8<)$ $\mathrm{mg} / \mathrm{L}, \mathrm{Ca}^{+2}(56-200<) \mathrm{mg} / \mathrm{dm}^{3}, \mathrm{Cl}^{-}(12.3-45) \mathrm{mg} / \mathrm{L}, \mathrm{Cl}_{2}(0-2.2) \mathrm{mg} / \mathrm{L}$, $\mathrm{PO}_{4}^{-3}(0.04-1.3) \mathrm{mg} / \mathrm{L}, \mathrm{NO}_{2}-\mathrm{N}(0.0006-2.9) \mathrm{mg} / \mathrm{L}, \mathrm{NH}_{3}-\mathrm{N}(0.001-0.5)$ $\mathrm{mg} / \mathrm{L}$. The high presence of heavy metals in water has recently been causing serious problems. Scientific research in the field of environmental toxicology has given us more and more answers to the questions of where many human health problems can come.
\end{abstract}

Keywords: Water, lime scale, boiler, heavy metals, toxicity, cancer

\section{INTRODUCTION}

Heavy metals have often been presented as one of the biggest public health problems. The removal of heavy metals with the term carcinogen is often inevitable by not detecting the source of where we can get these metals. The aim of every scientific researcher of medical, environmental, and food toxicology is to detect the main carcinogenic sources

\section{ÖZ}

Bu araştırma kazanlardaki atık içeriği yüksek olan kazan suyunun incelenmesine dayanmaktadır. Uzun yıllar kullanımının ardından, kazan içinde ağır elementler, iyonlar ve insan sağlığı için tehlikeli diğer moleküllerle karışmış olarak oldukça toksik kireç pulu oluşmaktadır. Ev tipi kazanlarda bazı ağır metallerin yüksek konsantrasyonda bulunması başlı başına bir sorundur. Çalışmamız kapsamında, ev tipi kazanların son derece yüksek konsantrasyonlarda birtakım ağır kanserojen metaller içerdiğine dair laboratuvar bulgularını ortaya koyduk. Ev tipi kazanlar, kazandaki atıkları temizlemek için basit bir sisteme sahip olmalıdır; bu kazanlar, araştırmamıza göre, normal metabolizmaya sahip bir kişide çok ciddi sorunlar yaratabilecek ağır metaller içermektedir. Ev tipi kazanlarda analiz edilen kimyasal parametreler şunlardır: $\mathrm{Cu}(0,002-3,08) \mathrm{mg} / \mathrm{L}, \mathrm{Fe}$ $(0,001-0,97) \mathrm{mg} / \mathrm{L}, \mathrm{Cr}^{+6}(0-0,31) \mathrm{mg} / \mathrm{L}, \mathrm{Al}^{+3}(0,001-0,8<) \mathrm{mg} / \mathrm{L}, \mathrm{Ca}^{+2}$ $(56-200<) \mathrm{mg} / \mathrm{dm}^{3}, \mathrm{Cl}^{-}(12,3-45) \mathrm{mg} / \mathrm{L}, \mathrm{Cl}_{2}(0-2,2) \mathrm{mg} / \mathrm{L}, \mathrm{PO}_{4}^{-3}(0,04-$ $1,3) \mathrm{mg} / \mathrm{L}, \mathrm{NO}_{2}-\mathrm{N}(0,0006-2,9) \mathrm{mg} / \mathrm{L}, \mathrm{NH}_{3}-\mathrm{N}(0,001-0,5) \mathrm{mg} / \mathrm{L}$. Suda yüksek miktardaki ağır metal mevcudiyeti son yıllarda ciddi sorunlara neden olmaktadır. Çevresel toksikoloji alanındaki bilimsel araştırmalar, birçok insan sağlığı sorununun nereden gelebileceğine dair sorulara giderek daha fazla yanıt verebilmektedir.

Anahtar Kelimeler: Su, kireç birikimi, kazan, ağır metaller, toksisite, kanser

of inorganic or organic character. As toxicology researhers, we have found high amounts of heavy metals in home boilers calling it the main source of carcinogens in a home. Why? In most cases, we have seen that hot water can often be used in the kitchen for the preparation of food products or anything else and the absence of information on what this type of water can bring in contact with lime scale (LS) could cause serious problems. In metabolism and the lab- 
oratory work is focused on what kind of carcinogenic metals may be in LS and what the consequences may be if our metabolism has contact with this type of water etc.

Heavy metals/metalloids are an important kind of pollutant that lead to a degradation of water quality. Trace metals in waters may originate from both natural and anthropogenic processes (1). Without information regarding physico-chemical parameters, water has often been the cause of many different diseases. According to this research, thermal devices contain very dangerous elements in LS that cause different diseases in people with normal metabolism. The combination of unit processes used in water treatment technological systems should ensure not only removal of pollutants present in normative values, but also guarantee water quality that should reduce the risk of secondary contamination during transport to the recipient (2). Chemical pollutants found in water boiler systems typically include calcium salts, magnesium, aluminium oxide, etc (3).

The toxicity of heavy metals has been documented throughout history by diagnosing the symptoms of heavy metal poisoning. Heavy metals pollution is a menace to our environment as they are the foremost contaminating agents of our food supply (4), also are well-known environmental pollutants due to their toxicity, persistence in the environment, and bio accumulative nature (5). Pollutants in LS boilers frequently present a major health risk including those with heavy metals with high potential for toxicity:

Iron can initiate cancer mainly by the process of oxidation of DNA molecules. This can sometimes result in cell death (6), or a spectrum of diseases with diverse clinical manifestations, ranging from anemia to iron overload, and possibly to neurodegenerative diseases (7).

Copper is widely distributed in nature and is an essential trace element for humans. Nonetheless, Cu (copper) shows some toxicological effects, damage to the renal tubules, brain, and other organs (8), high concentrations cause oxidative stress resulting in kidney, gastrointestinal tract, or liver damage (e.g., abdominal pain, cramps, nausea, diarrhea, and vomiting), which can be fatal (9), physiologic processes, such as angiogenesis; neurohormone homeostasis; and regulation of gene expression, brain development, pigmentation, and immune system functioning (10). However, copper toxicity has been reported in people who consume water containing high levels of copper as a result of stagnant water in coppercontaining pipes and fixtures as well as copper alloys in water distribution systems and household plumbing that allow copper to leach into water $(11,12)$.

Chromium is a mineral that humans require in trace amounts, although its mechanisms of action in the body and the amounts needed for optimal health are not well defined (13). The hexavalent chromium has been demonstrated to be associated with toxic parameters and classified as a human carcinogen and mutagen (14), particularly hexavalent chromium $\left(\mathrm{Cr}^{+6}\right)$ has been the greatest concern and is categorized as a group human carcinogen by the "International Agency for Research on Cancer".

Aluminium showed adverse effects on the nervous system and resulted in memory loss, problems with balance and coordination (15).

Ammonia is present in groundwater very often. Its presence in water describes its formation as the result of the reduction of organic substances containing nitrogen, and deamination of amines, etc (16).

Nitrites in the water supply system can also be reached due to their frequent use as a corrosion inhibitor during industry water processing (17). In humans, nitrite can cause methemoglobinemia, which is a specific type of anemia. Furthermore, nitrite has been observed to cause several types of cancer in animals and may potentially do so in humans (18).

According to many public health researchers, high concentrations of calcium in water cause cardiovascular problems in humans (19).

\section{MATERIAL AND METHOD}

During in this research the following parameters have been analysed in boiler water: copper (Cu), iron (Fe), chromium $\left(\mathrm{Cr}^{+6}\right)$, aluminium $\left(\mathrm{Al}^{+3}\right)$, calcium $\left(\mathrm{Ca}^{+2}\right)$, chlorine $\left(\mathrm{Cl}^{-}\right)$, phosphate $\left(\mathrm{PO}_{4}^{-3}\right)$, ammonia $\left(\mathrm{NH}_{3}-\mathrm{N}\right)$, nitrites $\left(\mathrm{NO}_{2}-\mathrm{N}\right)$, and chlorine $\left(\mathrm{Cl}_{2}\right)$. Analytical methods and DR / $2010 \mathrm{HACH}_{\diamond}$ spectrophotometry are used for the determination of these parameters in water LS inside the boilers. Spectrophotometer is very popular in water chemistry labs because it provides accurate results. We have described the general scientific form of LS in domestic boilers, see Figure 1.

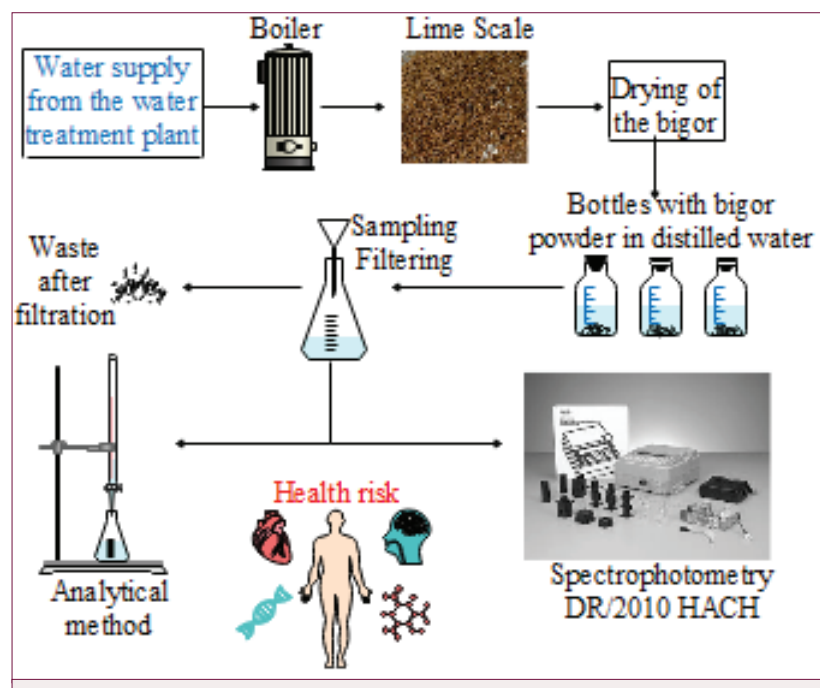

Figure 1. General description of the experimental study in high-volume domestic boilers water. 


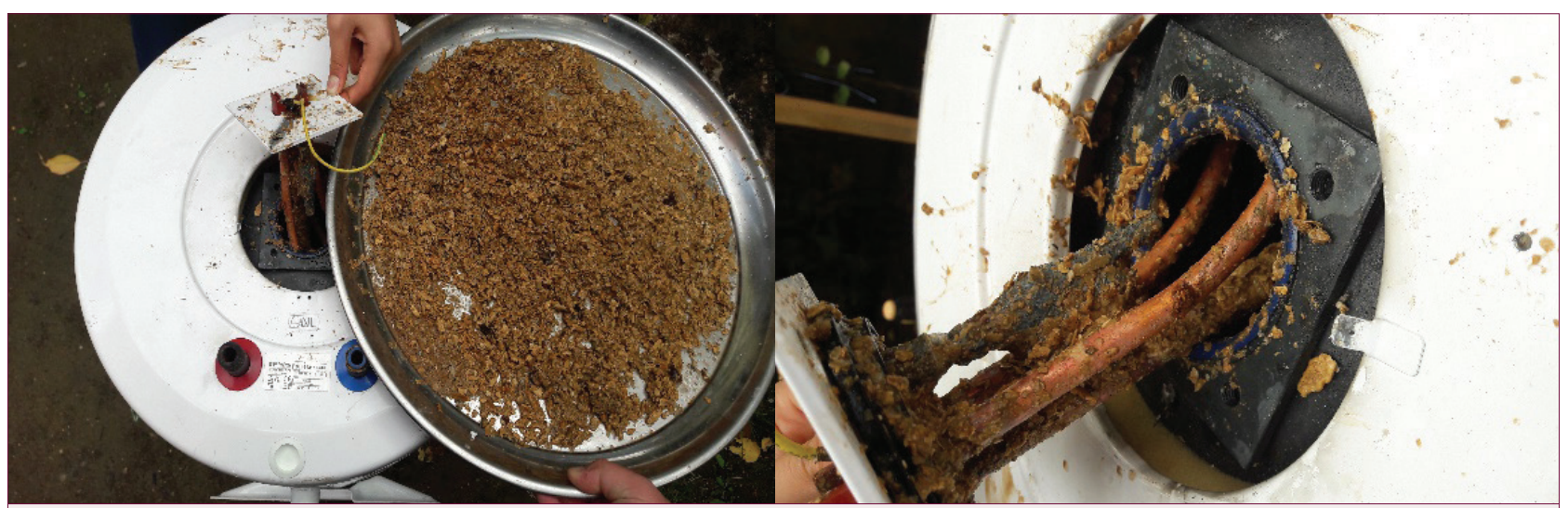

Figure 2. Sampling of LS in domestic boilers operating at temperatures $(60-75)^{\circ} \mathrm{C}$.

\section{Mechanical sampling way in boilers of different volume}

For the removal of the formed LS the mechanical method was used. Different tools can be used for the mechanical removal of LS. However, tools should be made of chrome as other metals can react chemically with the $L S$, see Figure 2 . Mechanical actions during the cleaning operation may result in damage of some parts of the boiler, so cleaners should have good knowledge of the constructive properties of the appliance and deal with them with great care (20). It should be noted that most domestic boilers operate $24 \mathrm{~h}$ at a temperature of $(60-75)^{\circ} \mathrm{C}$ and these boilers are supplied with municipal drinking water

\section{Treatment of samples after taking from domestic boiler}

After the mechanical cleaning of the boiler, the LS was carefully taken, placed in a dried chrome dish, and left drying for a few days. After drying, the LS was pressed in a very fine powder. This $200 \mathrm{~g}$ powder is placed with distilled water in a glass bottle with a volume of $2 \mathrm{~L}$, which has stood for two weeks at a temperature of $4-5^{\circ} \mathrm{C}$. Every day, three times a day, the glass bottle was shaken, so that the ions are as much in contact with distilled water as possible.

\section{Chemical reagents}

Phos Ver 3 reagent $\left(\mathrm{HACH}^{\circledR}\right)$, Ammonia Salicylate Reagent $\left(\mathrm{HACH}^{\circledR}\right)$, Ammonia Cyanurate Reagent $\left(\mathrm{HACH}^{\circledR}\right)$, ChromaVer
$3\left(\mathrm{HACH}^{\circledR}\right)$, FerroMo Iron Reagent $1\left(\mathrm{HACH}^{\circledR}\right)$, FerroMo Iron Reagent $2\left(\mathrm{HACH}^{\oplus}\right)$, CuVer $1\left(\mathrm{HACH}^{\oplus}\right)$, DPD Total Chlorine $\left(\mathrm{HACH}^{\oplus}\right), \mathrm{AgNO}_{3}(\mathrm{c}=0.01 \mathrm{~mol} / \mathrm{L}), \mathrm{K}_{2} \mathrm{CrO}_{4}(\mathrm{c}=0.257 \mathrm{~mol} / \mathrm{L})$, EDTA ( $c=0.01 \mathrm{~mol} / \mathrm{L}), \mathrm{NaOH}(\mathrm{c}=2 \mathrm{~mol} / \mathrm{L})$ and black murexide.

\section{Analyzed method and toxicological study of heavy and es- sential metals}

Use of the spectrophotometer for analytical analysis is one of the greatest advantages of analytical chemistry to detect essential metals and heavy metals that can cause serious problems in the human body. We, during the work in the laboratory have used powder fabricated for analysis by the company $\mathrm{HACH}^{\circledR}$ (Figure 3) to determine these heavy metals and the use of this experimental method enables us to have the most serious results for a scientific field like toxicology. This experimental part has enabled us to detect a domestic source of cancer such as water heating boilers and with the analyzed samples and the implementation of internationally known methods have managed to compile some very successful results for human health etc. Below we will describe the spectrophotometer $\left(\mathrm{HACH}^{\circledR}\right.$ Model DR/2010) methods used in laboratory experiments:

$\mathrm{PO}_{4}^{-3}$ (Method 8048, $\lambda=890 \mathrm{~nm}$ ), $\mathrm{NH}_{3}-\mathrm{N}$ (Method $8155, \lambda=655$ $\mathrm{nm}) . \mathrm{Cr}^{+6}$ (Hexavalent Chromium, Method 8023, $\lambda=540 \mathrm{~nm}$ ), Fe (Method 8365, $\lambda=590 \mathrm{~nm}$ ). Cu (Copper 9 Bicn Method 8506,

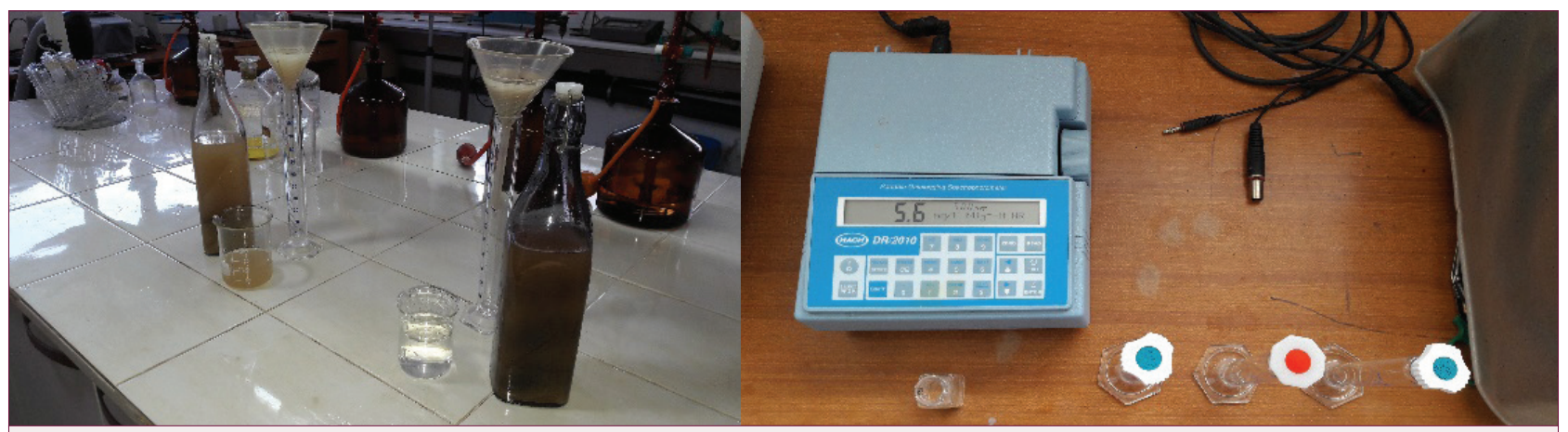

Figure 3. Analysis of chemical parameters in LS samples with $\mathrm{HACH}^{\circledR}$ Model DR/2010 spectrophotometer. 
$\lambda=560 \mathrm{~nm}$ ). $\mathrm{Cl}_{2}$ (Pocket Colorimeter II $\left(\mathrm{HACH}^{\circledR}\right.$ Chlorine Test, Method 8167). $\mathrm{Cl}^{-}$(Mercuric Thiocyanate Solution, Ferric Ion Solution, Method $8113, \lambda=455 \mathrm{~nm}$ ), while determining calcium by trituration we used these reagents: $5 \mathrm{ml}$ of buffer solution (in this issues $\mathrm{NaOH}$ (c=mol/L), black murexide indicator (black murexide, $\mathrm{NaCl}(\mathrm{c}=0.01 \mathrm{~mol} / \mathrm{L})$, and then titrated with ethylenediaminetetraacetic acid (EDTA) (c=0.01 mol/L), $5 \mathrm{~min}$ after the addition of $\mathrm{NaOH}$. The determination of $\mathrm{Ca}^{+2}$ was calculated by the following eq. (1): $(17,21)$.

$\mathrm{Ca}^{+2} \mathrm{mg} / \mathrm{L}=\frac{\mathrm{V}_{\text {EDTA }} \cdot \mathrm{C}_{\text {EDTA }} \cdot 56 \cdot 1000}{\mathrm{~V}_{\mathrm{s}}}$

where $V_{E D T A}$ is the volume $(\mathrm{ml})$ of the titre with EDTA, $C_{E D T A}$ is the concentration of EDTA ( $c=0.01 \mathrm{~mol} / \mathrm{L})$, and $V_{s}$ is the volume of the sample used.

\section{RESULTS AND DISCUSSION}

During the research, important results were obtained which helped determine which boiler samples were in the accordance with World Health Organization (WHO). The concertations that were not in accordance with $\mathrm{WHO}$ were divided in two groups. For more information, read the discussion of the results for each chemical parameter.

\section{Copper (Cu)}

Mass concentration of copper in this research was in the range from (0.002 -3.08) mg/L. Copper is one of the most important metals in this scientific research because of its high presence in the LS of boilers. The concentrations of $\mathrm{Cu}$ in the samples were divided in two groups: [i]. In the boiler samples $\mathrm{SP}_{1}, \mathrm{SP}_{3}, \mathrm{SP}_{4}, \mathrm{SP}_{6}, \mathrm{SP}_{7}, \mathrm{SP}_{8} \mathrm{SP}_{9}$ and $\mathrm{SP}_{10}$, the concentration of $\mathrm{Cu}$ is $(0.002-1.3) \mathrm{mg} / \mathrm{L}$ and that concentration is in line with WHO regulations (Table 1).

[ii]. In samples $\mathrm{SP}_{2}$ to $\mathrm{SP}_{5}$, the concentrations of $\mathrm{Cu}$ (2.013.08) $\mathrm{mg} / \mathrm{L}$ (Table 1) and Cu were not in line with the WHO allowed water regulation. The concertations of $\mathrm{Cu}$ in these samples contain a serious problem and open an important discussion for LS in domestic boilers.

\section{Iron (Fe)}

Iron in the samples $\mathrm{SP}_{1}$ to $\mathrm{SP}_{10}$ were not all in the category of chemically pure iron water, compared to WHO $(0.3 \mathrm{mg} / \mathrm{L})$. The Fe concertation in the boiler samples range from (0.001-0.97) $\mathrm{mg} / \mathrm{L}$. Some samples contained a high score of Fe and were not in accordance with WHO regulations. We will divide them in two groups according to the $\mathrm{WHO}$ regulation:

[i]. In the boiler samples $\mathrm{SP}_{4}, \mathrm{SP}_{9}$, and $\mathrm{SP}_{10}$, the concentrations of Fe are from (0.001- 0.2) mg/L, which mean that these concentrations were in accordance with WHO (Table 1).

[ii]. In boiler samples $\mathrm{SP}_{1}, \mathrm{SP}_{2}, \mathrm{SP}_{3}, \mathrm{SP}_{5}, \mathrm{SP}_{6}, \mathrm{SP}_{7}$, and $\mathrm{SP}_{8}$ the present concentration of Fe was from $(0.33-0.97) \mathrm{mg} / \mathrm{L}$, which meant that this concentration was higher than $0.2 \mathrm{mg} / \mathrm{L}$ and was not in line with WHO regulations (Table 1).

\section{Calcium $\left(\mathrm{Ca}^{+2}\right)$}

The concentration of $\mathrm{Ca}^{+2}$ in the boilers was very high and ranged from $56 \mathrm{mg} / \mathrm{L}$ to over $200 \mathrm{mg} / \mathrm{L}$ (Table 1). We divided the boiler samples in two groups, according to WHO regulation:

Table 1. Results of chemical parameters in water samples with LS of domestic boilers

\begin{tabular}{|c|c|c|c|c|c|c|c|c|c|c|}
\hline \multirow{2}{*}{$\begin{array}{l}\text { Unit } \\
\text { Samples (SP) }\end{array}$} & \multicolumn{10}{|c|}{ Chemical parameters (mg/L) } \\
\hline & $\mathrm{Cu}$ & $\mathrm{Fe}$ & $\mathrm{Cr}^{+6}$ & $\mathrm{Al}^{+3}$ & $\mathrm{Ca}^{+2}$ & $\mathrm{PO}_{4}^{-3}$ & $\mathrm{NO}_{2}-\mathrm{N}$ & $\mathbf{N H}_{\mathbf{3}}-\mathbf{N}$ & $\mathrm{Cl}_{2}$ & $\mathrm{Cl}^{-}$ \\
\hline $\mathrm{SP}_{1}$ & 0.29 & 0.46 & 0.05 & 0.001 & $>200$ & 0.09 & 1 & 0.14 & 0.48 & 22.3 \\
\hline $\mathrm{SP}_{2}$ & 3.08 & 0.97 & 0.31 & $>0.80$ & $>200$ & 0.71 & 2.9 & 0.41 & 2.2 & 20 \\
\hline $\mathrm{SP}_{3}$ & 0.46 & 0.33 & 0.08 & 0.006 & 146 & 0.06 & 0.6 & 0.9 & 1.6 & 25 \\
\hline $\mathrm{SP}_{4}$ & 0.1 & 0.2 & 0.004 & 0.09 & 56 & 0.04 & 0.8 & 0.04 & 1.4 & 45 \\
\hline $\mathrm{SP}_{5}$ & 2.01 & 0.8 & 0.28 & 0.4 & $>200$ & 0.64 & 3 & 0.7 & 1.1 & 12 \\
\hline $\mathrm{SP}_{6}$ & 1.3 & 0.9 & 0.12 & 0.1 & 147 & 1.3 & 1.5 & 0.25 & 1.9 & 23 \\
\hline $\mathrm{SP}_{7}$ & 0.9 & 0.51 & 0 & 0.001 & 59 & 0.08 & 0.9 & 0.5 & 0.56 & 14 \\
\hline $\mathrm{SP}_{8}$ & 1.6 & 0.6 & 0.09 & 0.02 & 150 & 0.45 & 1.1 & 0.17 & 1.5 & 19 \\
\hline $\mathrm{SP}_{9}$ & 0.002 & 0.001 & 0 & 0.0001 & $>200$ & 0.045 & 0.0008 & 0.001 & 0 & 18 \\
\hline $\mathrm{SP}_{10}$ & 0.003 & 0.003 & 0 & 0.0003 & $>200$ & 0.056 & 0.0006 & 0.002 & 0 & 12.3 \\
\hline $\begin{array}{l}\text { WHO reference values } \\
(\mathrm{mg} / \mathrm{L})(22)\end{array}$ & 2 & 0.3 & 0.05 & 0.2 & $<200$ & 0.2 & 0.5 & 0.5 & 0.2 & $<250$ \\
\hline
\end{tabular}


[i]. In the boiler samples $\mathrm{SP}_{3}, \mathrm{SP}_{4}, \mathrm{SP}_{6}, \mathrm{SP}_{7}$, and $\mathrm{SP}_{8}$, the concentration of $\mathrm{Ca}$ in sample ranges between $56 \mathrm{mg} / \mathrm{L}$ and $150 \mathrm{mg} / \mathrm{L}$ and were within WHO regulations (Table 1).

[ii]. In the boiler samples $\mathrm{SP}_{1}, \mathrm{SP}_{2}, \mathrm{SP}_{5}, \mathrm{SP}_{9}$, and $\mathrm{SP}_{10}$, the concentration of $\mathrm{Ca}^{+2}$ was more than $200 \mathrm{mg} / \mathrm{L}$ and were not in accordance with WHO regulations (Table 1).

\section{Hexavalent chromium $\left(\mathrm{Cr}^{+6}\right)$}

The concentration of $\mathrm{Cr}^{+6}$ in the ten samples ranged from (00.31) $\mathrm{mg} / \mathrm{L}$. In our research, $\mathrm{Cr}^{+6}$ in some boiler samples were not within WHO allowed regulations. We divided them into two groups according to $\mathrm{WHO}$ regulations:

[i]. In the boiler samples $\mathrm{SP}_{1}, \mathrm{SP}_{4}, \mathrm{SP}_{7}, \mathrm{SP}_{9}$, and $\mathrm{SP}_{10}$, the concentrations of $\mathrm{Cr}^{+6}$ in samples were within $\mathrm{WHO}$ regulations (Table 1).

[ii]. In boiler samples $\mathrm{SP}_{2}, \mathrm{SP}_{3}, \mathrm{SP}_{5}, \mathrm{SP}_{6}$, and $\mathrm{SP}_{8}$, the concentrations of $\mathrm{Cr}^{+6}$ in samples were not in accordance with WHO regulations, the concentration of $\mathrm{Cr}^{+6}$ was $0.31 \mathrm{mg} / \mathrm{L}$ (Table 1).

\section{Aluminium $\left(\mathrm{Al}^{+3}\right)$}

Aluminium as a metal has often demonstrated negative effects on people with a normal metabolism, as cited above. $\mathrm{Al}^{+3}$ in our research in most analysed samples was not in accordance with WHO water conditions (Table 1). The concentration of $\mathrm{Al}^{+3}$ in boiler samples ranged from $(0.0001-0.80) \mathrm{mg} / \mathrm{L}$. We divided the samples into two groups according to $\mathrm{WHO}$ regulations:

[i]. The first group included samples of boilers $\mathrm{SP}_{1}, \mathrm{SP}_{3}, \mathrm{SP}_{6}, \mathrm{SP}_{7}$, $\mathrm{SP}_{8}, \mathrm{SP}_{9}$, and $\mathrm{SP}_{10}$, in which $\mathrm{Al}^{+3}$ concentrations were in line with WHO (Table 1).

[ii]. The second group included boiler samples $\mathrm{SP}_{2}$ and $\mathrm{SP}_{5}$, in which the concentrations of $\mathrm{Al}^{+3}$ were very high. In $\mathrm{SP}_{5}$ the concentration was $0.4 \mathrm{mg} / \mathrm{L}$ and in $\mathrm{SP}_{2}$ above $0.80 \mathrm{mg} / \mathrm{L}$, which meant that these two samples were not in accordance with WHO.

\section{Phosphates $\left(\mathrm{PO}_{4}^{-3}\right)$}

Determination of phosphates $\left(\mathrm{PO}_{4}^{-3}\right)$ in water was unavoidable to control the quality of water. In the analysed boiler samples, the concentration of $\mathrm{PO}_{4}{ }^{-3}$ varied from $(0.04-1.3) \mathrm{mg} / \mathrm{L}$ and most of the samples had high concentrations of $\mathrm{PO}_{4}{ }^{-3}$. We divided the samples into two groups according to WHO regulations:

[i]. In boiler samples $\mathrm{SP}_{1}, \mathrm{SP}_{3}, \mathrm{SP}_{4}, \mathrm{SP}_{7}, \mathrm{SP}_{9}$, and $\mathrm{SP}_{10}$, the concentrations of $\mathrm{PO}_{4}{ }^{-3}$ were in accordance with WHO, concentrations were from (0.045-0.09) $\mathrm{mg} / \mathrm{L}$ (Table 1).

[ii]. In boiler samples $\mathrm{SP}_{2}, \mathrm{SP}_{5}$, and $\mathrm{SP}_{8}$, the concentrations of $\mathrm{PO}_{4}{ }^{-3}$ were not in line with $\mathrm{WHO}$, the concentrations were from (0.45-0.71) mg/L (Table 1).

\section{Nitrites $\left(\mathrm{NO}_{2}-\mathbf{N}\right)$}

Spectrophotometers are increasingly preferable for nitrite $\left(\mathrm{NO}_{2}-\mathrm{N}\right)$ determination, as the analytical method for nitrite determination cannot provide accurate results. In this research, the $\mathrm{NO}_{2}-\mathrm{N}$ was divided in two groups according to $\mathrm{WHO}$ : [i]. In the boiler samples $\mathrm{SP}_{9}$ and $\mathrm{SP}_{10}$, the concentrations of $\mathrm{NO}_{2}-\mathrm{N}$ were from $(0.006-0.008) \mathrm{mg} / \mathrm{L}$, in which two boilers did not contain high levels of $\mathrm{NO}_{2}-\mathrm{N}$ and were in accordance with WHO.

[ii]. The boiler samples $\mathrm{SP}_{1}, \mathrm{SP}_{2}, \mathrm{SP}_{3}, \mathrm{SP}_{4}, \mathrm{SP}_{5}, \mathrm{SP}_{6}, \mathrm{SP}_{7}$, and $\mathrm{SP}_{8}$ all contained high concentrations of $\mathrm{NO}_{2}-\mathrm{N}$. The $\mathrm{NO}_{2}-\mathrm{N}$ concentration in these samples ranged from $(0.6-2.9) \mathrm{mg} / \mathrm{L}$, which was not in line with WHO (Table 1).

\section{Ammonia $\left(\mathrm{NH}_{3}-\mathrm{N}\right)$}

From the environmental chemistry theories, it is known that $\mathrm{NH}_{3}-\mathrm{N}$ presents a major problem in surface water and groundwater. In some analysed samples, $\mathrm{NH}_{3}-\mathrm{N}$ was present in high levels and we divided them in two groups according to WHO:

[i]. In boiler samples $\mathrm{SP}_{7}, \mathrm{SP}_{9}$, and $\mathrm{SP}_{10}$ did not contain a high concentration of $\mathrm{NH}_{3}-\mathrm{N}$. Concentrations ranged from (0.001$0.5) \mathrm{mg} / \mathrm{L}$ and these samples corresponded with the WHO water regulations (Table 1 ).

[ii]. In boiler samples $\mathrm{SP}_{1}, \mathrm{SP}_{2}, \mathrm{SP}_{3}, \mathrm{SP}_{4}, \mathrm{SP}_{5}, \mathrm{SP}_{6}$, and $\mathrm{SP}_{8}$ were not in accordance with the $\mathrm{WHO}$ because they contained high concentrations of $\mathrm{NH}_{3}-\mathrm{N}$ approximately $0.41 \mathrm{mg} / \mathrm{L}$ (Table 1).

\section{Chlorides $\left(\mathrm{Cl}^{-}\right)$}

In all boiler samples that were analysed, unlike all the other analysed chemical parameters, the chlorides were in agreement with WHO permissible values as their concertations ranged from (12-45) mg/L (Table 1).

\section{Chlorine $\left(\mathrm{Cl}_{2}\right)$}

The concentration of chlorine in these samples was very high compared to WHO's permissible values. The concentration of $\mathrm{Cl}_{2}$ in the analysed samples in the boilers supplied with different water treatment plant so $\mathrm{Cl}_{2}$ was deposited in the $\mathrm{LS}$, specifically inside the domestic boiler, which means that $\mathrm{Cl}_{2}$ is a major concern for health. It is known that disinfection of chlorinated water with gases can be made from (0.2-0.5) $\mathrm{mg} / \mathrm{L}$. In this scientific research of samples analyses, $\mathrm{Cl}_{2}$ ranges is from (0-2.2) $\mathrm{mg} / \mathrm{L}$. Some samples that were not in accordance with $\mathrm{WHO}$, were divided in two groups:

[i]. Sampling boilers $\mathrm{SP}_{1}, \mathrm{SP}_{9}$, and $\mathrm{SP}_{10}$ did not contain high concentrations of $\mathrm{Cl}_{2}$, which varied from (0-0.48) $\mathrm{mg} / \mathrm{L}$. These concentrations were within the WHO parameters (Table 1).

[ii]. In the samples of boilers $\mathrm{SP}_{2}, \mathrm{SP}_{3}, \mathrm{SP}_{4}, \mathrm{SP}_{5}, \mathrm{SP}_{6}, \mathrm{SP}_{7}$, and $\mathrm{SP}_{8}$, contained high concentrations of $\mathrm{Cl}_{2}$ from $(0.56-2.2) \mathrm{mg} / \mathrm{L}$. These concentrations of $\mathrm{Cl}_{2}$ were not in accordance with $\mathrm{WHO}$ permissible values (Table 1).

\section{CONCLUSION}

We, as scientific researchers have been able to provide scientific proof in this research that domestic boilers today are very dangerous in the formation of LS. Domestic boilers with LS contain heavy metals with carcinogenic properties in the samples we studied and this research shows very serious problem especially in DNA damage and other problems in human health. The 
chemical parameters with the highest concentration of toxicity in some samples in our research are: $\left(\mathrm{Cu}, \mathrm{Fe}, \mathrm{Cr}^{+6}, \mathrm{Al}^{+3}, \mathrm{Ca}^{+2}\right.$, $\mathrm{PO}_{4}{ }^{-3}, \mathrm{NO}_{2}-\mathrm{N}, \mathrm{NH}_{3}-\mathrm{N}, \mathrm{Cl}_{2}$ ) mg/L.

Cu as a heavy metal in our research was not in accordance with WHO, Cu concentrations were up to $3.08 \mathrm{mg} / \mathrm{l}$. Fe as a heavy metal for the human body can often become toxic when the Fe concentration is not in accordance with WHO, in our study the concentrations of Fe reaches up to $0.97 \mathrm{mg} / \mathrm{L}$. $\mathrm{Cr}^{+6}$ and is one of the most dangerous and toxic chemical parameters due to these high levels. In our scientific research, the concentration of $\mathrm{Cr}^{+6}$ is up to $0.31 \mathrm{mg} / \mathrm{L}$ and was not in condition with $\mathrm{WHO}$. $\mathrm{Al}^{+3}$ as a frequent hazardous parameter in water is a concern, especially when the high concentration reaches more than $0.8 \mathrm{mg} / \mathrm{L}$ as in our research. $\mathrm{Ca}^{+2}$ as an important chemical parameter in water sometimes causes health problems if $\mathrm{Ca}^{+2}$ is high, especially when exceeding $200 \mathrm{mg} / \mathrm{L}$ which is unhealthy for normal human metabolism and in our research the concentration of $\mathrm{Ca}^{+2}$ was not in accordance with WHO because the concentration of $\mathrm{Ca}^{+2}$ was $>200 \mathrm{mg} / \mathrm{L}$. The high presence of $\mathrm{Cl}_{2}$ in water with $\mathrm{LS}$ represents another health concern that may cause $\mathrm{Cl}_{2}$. The concentration of $\mathrm{Cl}_{2}$ in our research was $2.2 \mathrm{mg} / \mathrm{L}$ which means it was not in line with $\mathrm{WHO}$. The concentration of $\mathrm{PO}_{4}^{-3}$ in our samples was approximately $1.3 \mathrm{mg} / \mathrm{L}$ so the concentration of $\mathrm{PO}_{4}^{-3}$ in our samples was so high and not in accordance with WHO. The high concentration of $\mathrm{NO}_{2}-\mathrm{N}$ and $\mathrm{NH}_{3}-\mathrm{N}$ in the water causes toxicity, the concentration of $\mathrm{NO}_{2}-\mathrm{N}$ was $2.9 \mathrm{mg} / \mathrm{L}$ in our analyzed samples, this high concentration of $\mathrm{NO}_{2}-\mathrm{N}$ was not in accordance with $\mathrm{WHO}$ but the concentration of $\mathrm{NH}_{3}-\mathrm{N}$ at $0.5 \mathrm{mg} / \mathrm{L}$, was in accordance with WHO. Water in contact with LS used in the kitchen for food or other forms can cause carcinogenic effects on the normal metabolism of humans.

Ethics Committee Approval: Ethics committee approval is not required because of no material or experimental animal that would require permission.

Peer-review: Externally peer-reviewed.

Author Contributions: Conception/Design of study - V.M.B.; Data Acquisition - V.M.B.; Data Analysis/Interpretation - V.M.B.; Critical Revision of Manuscript - A.K; K.K.; Technical or Material Support - F.K.

Conflict of Interest: The authors have no conflict of interest to declare.

Financial Disclosure: The authors declared that this study has received no financial support.

Etik Komite Onayı: Bu çalışmada, etik komite iznine gerek duyulacak bir materyal ya da deney hayvanı kullanılmamıştır.

Hakem Değerlendirmesi: Dış bağımsız.

Yazar Katkıları: Çalışma Konsepti/Tasarımı - V.M.B.; Veri ToplamaV.M.B.; Veri Analizi/Yorumlama -V.M.B.; İçeriğin Eleştirel İncelemesi - A.K; K.K.; Malzeme ve teknik destek - F.K.

Çıkar Çatışması: Yazarlar çıkar çatışması bildirmemişlerdir.

Finansal Destek: Yazarlar bu calışmada finansal destek almadıklarını beyan etmişlerdir.

\section{REFERENCES}

1. Wu J, Man Y, Sun G, Shang L. Occurrence and Health-Risk Assessment of Trace Metals in Raw and Boiled Drinking Water from Rural Areas of China. Water 2018; 10: 1-15. [CrossRef]

2. Domoń A, Papciak D, Tchórzewska-Cieślak B, Pietrucha-Urbanik B. Biostability of Tap Water - A Qualitative Analysis of Health Risk in the Example of Groundwater Treatment (Semi-Technical Scale). Water 2018; 10: 1-13. [CrossRef]

3. Daci N, Daci-Ajvazi M. Shkenca e Mjedisit. Akademia e Shkencave të Kosovës. Prishtinë; 2014. pp. 436, 475.

4. Kacholi DS, Sahu M. Levels and Health Risk Assessment of Heavy Metals in Soil, Water, and Vegetables of Dar es Salaam, Tanzania. Journal of Chemistry 2018; 1-9. [CrossRef]

5. Ali $\mathrm{H}$, Khan E, llahi I. Environmental Chemistry and Ecotoxicology of Hazardous Heavy Metals: Environmental Persistence, Toxicity, and Bioaccumulation. Journal of Chemistry 2019; 1-14. [CrossRef]

6. Jose E, Dutra-De-Oliveira J, Marchini S, Lamounier J, Carlos A, Almeida N. Iron-Fortified Drinking Water Studies for the Prevention of Children's Anemia in Developing Countries. Anemia 2011; 1-5. [CrossRef]

7. Abbaspour N, Hurrell R, Kelishadi R. Review on iron and its importance for human health. J Res Med Sci 2014; 19: 164-74.

8. Gholivand M, Pourhossein A. Simultaneous Determination of Copper and Cadmium in Environmental Water and Tea Samples by Adsorptive Stripping Voltammetry. Turkish Journal of Chemistry 2011; 35: 839-846.

9. Chubaka CE, Whiley H, Edwards JW, Ross KE. Lead, Zinc, Copper, and Cadmium Content of Water from South Australian Rainwater Tanks, Int. J. Environ. Res. Public 2018; 15: 1-12. [CrossRef]

10. Collins JF. Copper. In: Ross AC, Caballero B, Cousins RJ, Tucker KL, Ziegler TR, eds. Modern Nutrition in Health and Disease. 11th ed. Baltimore, MD: Lippincott Williams \& Wilkins; 2014. pp. 206-16.

11. Institute of Medicine. Food and Nutrition Board. Dietary Reference Intakes: Thiamin, Riboflavin, Niacin, Vitamin B6, Folate, Vitamin B12, Pantothenic Acid, Biotin, and Choline. Washington, DC: National Academy Press; 1998.

12. National Research Council Committee on Copper in Drinking Water. Copper in Drinking Water. Washington, DC: National Academies Press; 2000.

13. U.S. Department of Health \& Human Services. National Institutes of Health. Strengthening Knowledge and Understanding of Dietary Supplements. Chromium Dietary Supplement Fact Sheet. https://ods.od.nih.gov/factsheets/Chromium-HealthProfessional/ (acess:10.07.2020)

14. Beluli V, Mulliqi I. Heavy Metals as Main Polluting Factors in the Mirusha, Stanishor and Morava Rivers in Gjilan, Kosovo. JOTCSA 2019; 6: 89-96. [CrossRef]

15. Jaishankar M, Teseten T, Anbalagan N, Mathew B, Beeregowda KN. Toxicity, Mechanism and Health Effects of Some Heavy Metals, Interdiscip. Toxicol 2014; 7: 60-72. [CrossRef]

16. Beluli V. Assessment of Groundwaters' Quality with Depth of (8$60) \mathrm{m}$ in the Arbëria Neighbourhood of Gjilan Municipality, Kosovo. JOTCSA 2019; 6: 419-28. [CrossRef]

17. Korça B. Analiza Kimike të Ujit. Universiteti i Prishtinës "Hasan Prishitna", Prishtinë; 2013. p. 99, 100-101, 108, 110.

18. Rantanen PL, Mellin I, Keinänen-Toivola NM, Ahonen M, Vahala R. The Seasonality of Nitrite Concentrations in a Chloraminated Drinking Water Distribution System. International Journal of Environmental Research and Public Health 2018; 15: 1-17. [CrossRef] 
19. U.S. Department of Health \& Human Services. National Institutes of Health. Strengthening Knowledge and Understanding of Dietary Supplements. Calcium Fact Sheet. https://ods.od.nih.gov/ factsheets/Calcium-Consumer/ (acess:08.08.2020)

20. Agolli F. Teknologjia Kimike Inorganike, Universiteti i Prishtinës, Mitrovicë, 1983; pp. 67-8.
21. Beluli VM. Influence of Urbanization and Industries on the Pollution of Rivers of Gjilan Municipality, Kosovo, Kem. Ind 2018; 67: 517-25. [CrossRef]

22. Guidelines for drinking-water quality: fourth edition incorporating the first addendum. Geneva:World Health Organization; 2017.

\section{ANNEX A. Heavy metal concentration diagrams in the analysed samples}
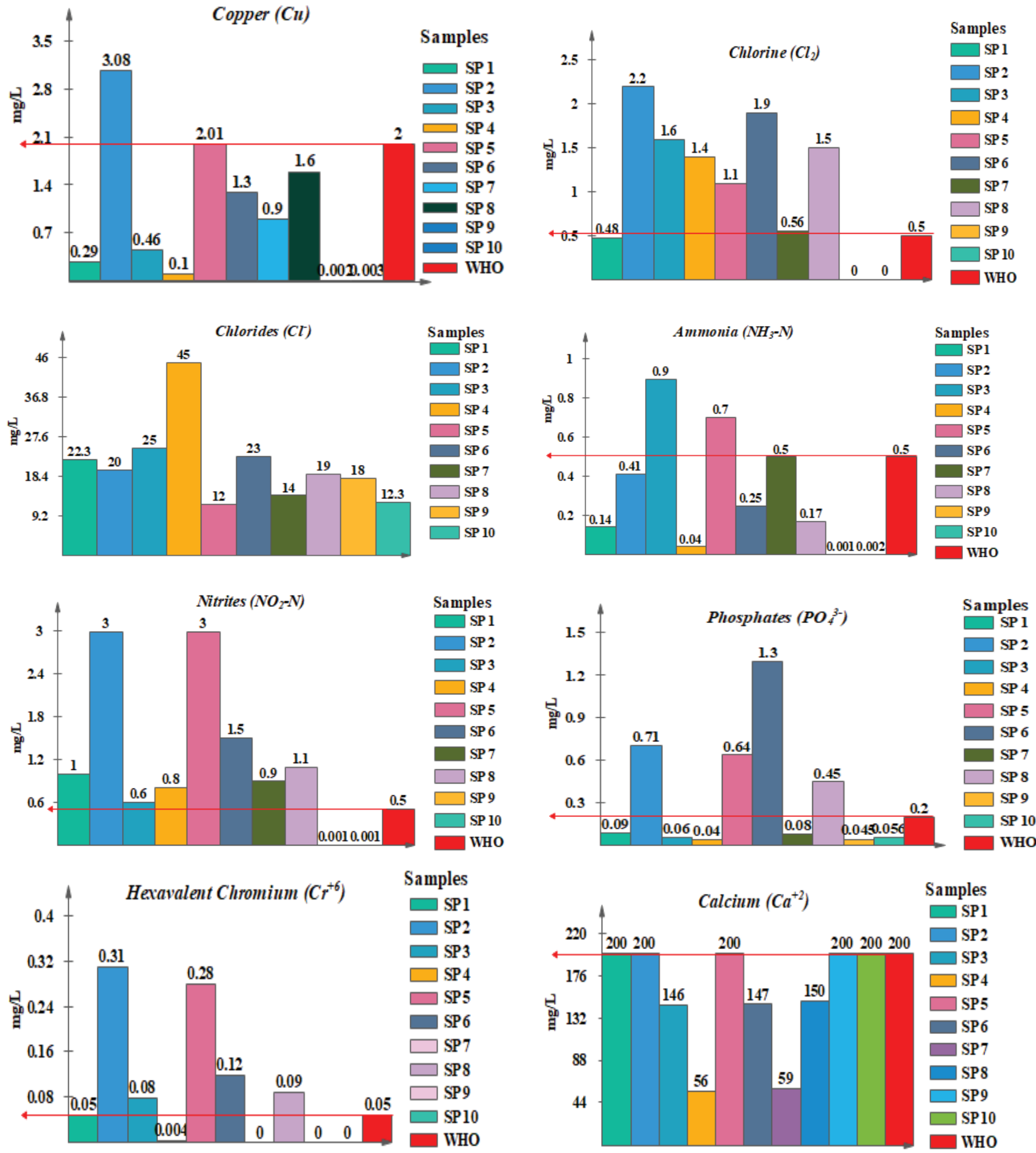